\title{
PENGARUH HARGA DIRI DAN KEPERCAYAAN TERHADAP PENGUNGKAPAN DIRI PADA PENGGUNA APLIKASI KENCAN ONLINE
}

THE EFFECT OF SELF ESTEEM AND TRUST IN SELF DISCLOSURE ONLINE DATING APPLICATION USER

\section{Iin Andriani ${ }^{(1)}$, Diana Imawati ${ }^{(2)}$, Siti Khumaidatul Umaroh ${ }^{(3)}$}

Fakultas Psikologi, Universitas 17 Agustus 1945 Samarinda $^{(1)}$, Fakultas Psikologi, Universitas 17 Agustus 1945 Samarinda ${ }^{(2)}$, Fakultas Psikologi, Universitas 17 Agustus 1945 Samarinda ${ }^{(3)}$

E-mail: iinandriani172@gmail.com ${ }^{(1)}$,Diana_ima@yahoo.co.id ${ }^{(2)}$, sitikhumaidatulumaroh@yahoo.co.id ${ }^{(3)}$

\begin{abstract}
Abstrak : Penelitian ini bertujuan untuk mengukur pengaruh self esteem dan trust terhadap self disclosure pengguna aplikasi kencan online. Sampel penelitian ini berjumlah 325 responden. Teknik penetapan sampel ini menggunakan teknik quota sampling. Data penelitian dikumpulkan menggunakan tiga jenis kuisioner yang mengukur self disclosure, self esteem dan trust. Teknik analisa data menggunakan korelasi spearman dengan bantuan program statistik SPSS 23 for windows. Hasil penelitian menunjukan bahwa terdapat korelasi yang signifikan antara self esteem dan self disclosure rho $=0,394 ; \mathrm{p}=0,000$ ). Serta terdapat korelasi yang signifikan antara trust dan self disclosure $(\mathrm{rho}=0,475 ; \mathrm{p}=0,000)$. Dalam hal ini self esteem mempengaruhi self disclosure sebesar $15,5 \%$, sedangkan trust mempengaruhi self disclosure sebesar $22,5 \%$.

Kata Kunci : Pengungkapan diri, Harga diri, Kepercayaan, Kencan online

Abstract : This study aims to measure the effect of self esteem and trust on self disclosure of online dating application users. The sample of this research is 325 respondents. This sampling technique uses quota sampling technique. Research data were collected using three types of questionnaires that measure self disclosure, self esteem and trust. Data analysis techniques using the Spearman correlation with the help of the statistical program SPSS 23 for Windows. The results showed that there was a significant correlation between self esteem and self disclosure with a rho value of 0.394. And there is a significant correlation between trust and self disclosure with a rho value of 0.475 . With a significant level of $0,000(p<0.01)$. In this case self-esteem affects self-disclosure by $15.5 \%$, while trust affects self-disclosure by $22.5 \%$.
\end{abstract}

Keywords: Self Disclosure, Self Esteem, Trust, Online Dating 


\section{PENDAHULUAN}

Dewasa ini dunia tengah berada pada era milenial dimana setiap aspek dalam kehidupan memanfaatkan teknologi modern. Salah satu ciri pemanfaatan teknologi modern yang dapat dilihat adalah tingginya pemanfaatan internet. Pada tahun 2017 data yang tercatat oleh Asosiasi Pengguna Jasa Internet Indonesia (APJJI) di Indonesia sebanyak 143,6 juta $(54,68 \%)$ dari total populasi merupakan pengguna aktif internet. Pemanfaatan teknologi modern dan internet yang tinggi mampu membawa perubahan dalam cara berkomunikasi yakni dari cara tatap muka (offline) yang saat ini dapat dilakukan secara online. Perubahan cara berkomunikasi ini pada akhirnya juga membawa perubahan dalam cara menemukan teman atau pasangan, yakni dengan menggunakan layanan aplikasi kencan online.

Berdasarkan data yang tercatat oleh APJJI pengguna internet terbanyak di Indonesia berada pada kelompok usia 19-34 tahun. Hurlock (2003) menyebutkan usia tersebut termasuk dalam usia dewasa awal, yakni dimulai dari umur 18 tahun sampai dengan sekitar umur 40 tahun. Pada usia dewasa awal individu memiliki tugas perkembangan berupa membangun hubungan dan menemukan cinta mendalam (Upton, 2012). Havrighurst (Hurlock, 2003) juga menyebutkan tugas perkembangan lainnya yakni memilih pasangan dan mulai membina keluarga.

Layanan kencan online merupakan industri yang melayani sebagian orang dewasa (Rosen, 2007). Kehadiran kencan online dapat memfasilitasi kebutuhan individu dewasa awal untuk memenuhi tugas perkembangan dalam mencari pasangan atau membangun hubungan romantis. Hal ini sesuai dengan penelitian Mikyoung, Kyoung dan Mira (2009) yang menemukan bahwa motivasi utama untuk menggunakan layanan kencan internet adalah mencari hubungan romantis.

Layanan kencan online juga menawarkan kemudahan berupa kebebasan untuk diakses oleh semua orang tanpa memandang usia pengguna, jenis kelamin, atau pekerjaan. Pada konteks yang sama kemungkinan manfaat terbanyak yang dapat diambil dari layanan kencan online adalah bagi orang-orang yang memiliki karakteristik tertentu. McKenna dkk (Rubin \& Coplan, 2010) menyebutkan karakteristik tersebut berupa rasa malu, kecemasan sosial, atau kurangnya keterampilan sosial. Serta mereka yang memiliki pengalaman dikecewakan atau kesulitan mendapatkan pasangan di dunia riil (Kasali, 2018).

Pada aplikasi kencan online pengguna memulai kontak awal (interaksi awal) pada sesi chat personal dengan berbagi informasi diri (self disclosure). Pada kencan online pembentukan romansa online sangat dipengaruhi oleh proses cepat "mengenal anda" secara online (self disclosure) dan juga hal ini sebagai syarat utama pengembangan hubungan romansa online (Rosen; 2007, Ward; 2016, Ben-Ze'ev; 2004).

Self disclosure (pengungkapan diri) merupakan jenis komunikasi dimana individu mengungkapkan informasi tentang diri sendiri yang biasanya disembunyikan (Devito, 2011). Devito (Pinakesti, 2016) menyebutkan bahwa self disclosure terdiri dari lima dimensi yakni: amount (ukuran atau jumlah), valence, ccuracy/honesty (kecermatan/kejujuran), Intention (tujuan atau maksud), intimacy (keintiman).

Menurut Morissan (2010) Bagi pasangan individu yang baru saling mengenal, percakapan personal yang mengungkapkan informasi pribadi kepada individu lain menjadi satu-satunya cara untuk saling mengenal agar mereka dapat lebih mengerti satu sama lain. Santrock (2011) menyebutkan bahwa keterbukaan dan berbagi pikiran-pikiran personal merupakan tanda keintiman. Pada masa dewasa awal mengelola tuntutan akan keintiman, identitas dan kemandirian merupakan tugas utama. Erikson (Santrock, 2011) menyebutkan bahwa keintiman pada masa dewasa merupakan proses menemukan diri sendiri sekaligus peleburan diri sendiri di dalam diri orang lain. Apabila individu gagal mengembangkan relasi yang intim di masa dewasa awal maka ia akan mengalami isolasi.

Johnson (Gainau, 2009) menunjukkan bahwa individu yang mampu dalam membuka diri (self disclosure) akan dapat mengungkapkan diri dengan tepat; terbukti mampu menyesuaikan diri (adaptif, lebih percaya diri, lebih kompeten, dapat diandalkan, lebih mampu bersikap postif percaya terhadap orang lain, lebih objektif dan terbuka. sebaliknya individu yang kurang mampu dalam self disclosure terbukti tidak mampu 
menyesuaikan diri, kurang percaya diri, timbul perasaan takut, cemas, merasa rendah diri dan tertutup. Johnson menyebutkan bahwa ciri-ciri self disclosure tersebut, mempengaruhi kesehatan mental seseorang.

Studi terdahulu menemukan bahwa terdapat berbagai faktor yang dapat mempengaruhi self disclosure salah satunya yakni self esteem dan trust. Coopersmith (Lumongga, 2016) mendefinisikan self esteem sebagai evaluasi yang dibuat dan kebiasaan dalam memandang dirinya, terutama mengenai sikap menerima dan menolak, dan merupakan indikasai dari besaran kepercayaan terhadap kemampuan, keberartian, kesuksesan dan keberhargaan. Rosenberg (Lumongga, 2016) menggambarkan self esteem sebagai sikap suka atau tidak suka terhadap diri sendiri. Coopersmith (Dewi, 2009) menyebutkan bahwa self esteem terdiri dari empat aspek yakni: power (kekuatan), significance (keberartian), virtue (kebajikan), competence (kemampuan).

Komunikasi antara pasangan kencan online akan lebih lancar apabila individu berani dan mampu untuk mengungkapkan pikiran dan perasaannya. Perasaan berani dan mampu untuk mengungkapkan pikiran dan perasaan didasarkan pada penerimaan serta penilaian individu terhadap dirinya sendiri yakni self esteem. Individu yang memiliki self esteem yang tinggi akan lebih mudah mengadakan relasi dan komunikasi dibandingkan dengan yang rendah (Riyanto \& Susanto, 2009). Hal ini dikarenakan individu yang memiliki self esteem yang tinggi akan mampu untuk menghargai dirinya sendiri tanpa harus tergantung pada penilaian orang lain tentang sifat atau kepribadiannya baik itu positif maupun negatif (Santi \& Damariswara, 2017). Sehingga individu tersebut tidak akan mengalami hambatan dalam mengungkapkan diri dikarenakan ia mampu untuk bersikap asertif, terbuka, dan memiliki kepercayaan terhadap dirinya.

Individu yang memiliki self esteem rendah selalu bersikap pesimis dan tidak bisa, kemudian akan mengalami kegagalan, ketidakpuasaan, lalu menjadi rendah diri (Riyanto \& Susanto, 2009). Individu tersebut akan mengalami hambatan dalam mengungkapkan diri dikarenakan adanya rasa malu untuk berterus terang tentang perasaan, keinginan dan hal-hal yang tidak baik bila diketahui orang lain (Sari, Andayani \& Masykur, 2006). Kekhawatiran untuk membuka diri kepada orang lain ini berkaitan dengan resiko yang akan diterima, misalnya bila kelemahannya diketahui oleh orang lain.

Rempel dkk (Yulianti, 2015) menyebutkan trust adalah salah satu kualitas yang paling dikehendaki dalam hubungan intim. Hal ini sering dikaitkan dengan hubungan cinta dan komitmen antar pasangan sebagai landasan hubungan yang ideal. Hasbullah (Suaib,2017) menyebutkan rasa percaya (trust) sebagai suatu bentuk keinginan untuk mengambil resiko dalam hubungan-hubungan sosial yang didasari perasaan yakni bahwa orang lain akan melakukan sesuatu seperti yang diharapkan dan akan selalu bertindak dalam suatu pola yang saling mendukung. Rempel dkk (Taneira, 2019) menyebutkan bahwa trust terdiri dari tiga aspek yakni: predictability (keadaan yang dapat diperkirakan), dependability (keadaan yang dapat diandalkan), faith (keyakinan).

Trust merupakan salah satu hal yang menumbuhkan hubungan dan komunikasi interpersonal, bila individu percaya pada seseorang dan yakin orang tersebut tidak akan merugikannya maka individu tersebut akan semakin membuka diri pada orang tersebut. Menurut Johnson (Putri \& Kusumaputri, 2014) kepercayaan merupakan aspek dalam suatu hubungan dan secara terus menerus berubah serta bervariasi yang dibangun melalui rangkaian tindakan trusting dan trustworthy. Trusting adalah kemauan untuk mengambil resiko terhadap akibat yang baik ataupun buruk. Sedangkan trustworthy adalah perilaku yang melibatkan penerimaan terhadap kepercayaan orang lain.

Individu yang memiliki trust yang tinggi dan berada dalam keadaan acceptane akan mampu untuk mengemukakan pemikiran, ideide, kesimpulan-kesimpulan, perasaan dan reaksinya. Sehingga ia mampu untuk asertif dan pada akhirnya mampu untuk melakukan self disclosure. Sedangkan individu yang memiliki trust yang rendah dan tidak berada dalam keadaan acceptance akan memiliki hambatan dalam melakukan self disclosure. Hal ini dikarenakan individu tersebut tidak mampu untuk mengemukakan pemikiran, ide-ide, kesimpulankesimpulan, perasaan dan reaksinya. Sehingga ia 
tidak mampu untuk asertif dan pada akhirnya mampu untuk melakukan self disclosure.

Berdasarkan penjelasan tersebut, dan berdasarkan kajian yang telah dilakukan oleh peneliti, penelitian terhadap variable self esteem dan trust terhadap self disclosure belum pernah diteliti secara bersaman. Hal ini yang membawa peneliti untuk melakukan penelitian tentang pengaruh self esteem dan trust terhadap self disclosure pengguna kencan online

\section{METODE}

Penelitian ini dilakukan pada 325 pengguna aplikasi kencan online yang berusia 18-40 tahun. Tehnik sampling menggunakan non random sampling yakni quota sampling. Pengambilan data menggunakan kuesioner online. Alat ukur dalam penelitian ini yakni menggunakan skala psikologi self disclosure oleh Pinakesti (2016), skala psikologi self esteem oleh Dewi (2009), dan skala psikologi trust oleh Taneira (2019) yang kemudian dimodifkasi sesuai kebutuhan penelitian. Standar koefisien validitas yang digunakan yakni 0,30 . Nilai reabilitas pada skala psikologi self disclosure sebesar 0,919, skala psikologi self esteem sebesar 0,853 , dan skala psikologi trust sebesar 0,906. Data penelitian dianalisis dengan menggunakan uji korelasi spearman. Penggunaan uji korelasi spearman didasarkan atas tidak terpenuhinya uji prasyarat yakni normalitas data.

\section{HASIL}

Berdasarkan kuesioner yang telah di kumpulkan, data penelitian kemudian dibagi menjadi tiga kategori. Detail distribusi data penelitian dapat dilihat dari tabel berikut:

Tabel 1 Kategori Self Disclosure

Responden

\begin{tabular}{ccc}
\hline Kategori & Frekuensi & Persentase \\
\hline Rendah & 86 & $26,5 \%$ \\
Sedang & 234 & $72 \%$ \\
Tinggi & 5 & $1.5 \%$ \\
\hline Total & 325 & $100 \%$
\end{tabular}

Tabel 2 Kategori Self Esteem Responden

\begin{tabular}{ccc}
\hline Kategori & Frekuensi & Persentase \\
\hline Rendah & 106 & $32,6 \%$ \\
Sedang & 197 & $60,6 \%$ \\
Tinggi & 22 & $6,8 \%$ \\
\hline Total & 325 & $100 \%$
\end{tabular}

Tabel 3 Kategori Trust Responden

\begin{tabular}{ccc}
\hline Kategori & Frekuensi & Persentase \\
\hline Rendah & 106 & $32,6 \%$ \\
Sedang & 197 & $60,6 \%$ \\
Tinggi & 22 & $6,8 \%$ \\
\hline Total & 325 & $100 \%$
\end{tabular}

Berdasarkan hasil uji asumsi diketahui bahwa uji normalitas memperoleh nilai signifikansi sebesar $0,000(\mathrm{P}<0,05)$. Hal ini dimaknai bahwa data ke tiga variable tidak berdistribusi secara normal. Sedangkan berdasarkan uji linearitas antara self esteem dan self disclosure diperoleh nilai deviation from linearity sebesar 0,828 , serta trust dan self disclosure dengan nilai deviation from linearity sebesar 0,537. Maka dapat dikatakan bahwa ada hubungan yang linear antara self disclosure dan self esteem, dan ada hubungan yang linear antara self disclosure dan trust.

Berdasarkan uji korelasi terhadap variabel independen diketahui bahwa seluruh variabel bebas berkorelasi dengan variabel terikat: self esteem dan self disclosure $(\mathrm{rho}=0,394 ; \mathrm{p}<0,05$; berkorelasi lemah); trust dan self disclosure $\quad(\mathrm{rho}=0,475 ; \quad \mathrm{p}<0,05$ berkorelasi sedang). Berdasarkan hasil yang ditemukan tersebut maka dapat disimpulkan bahwa terdapat korelasi yang positif dan signifikan antara self esteem dan trust terhadap self disclosure pengguna aplikasi kencan online. Self esteem mempengaruhi self disclosure sebesar 15,5\%. Sedangkan Trust mempengaruhi sebesar $22,5 \%$. 


\section{DISKUSI}

Self esteem mepengaruhi self disclosure sebesar $15,5 \%$ dan memiliki hubungan yang berkekuatan lemah. Penyebab lemahnya hubungan antara self esteem dan self disclosure dalam penelitian ini berkaitan dengan kompetensi dan kepribadian yang dimiliki oleh responden. Berdasarkan deskripsi penelitian berkaitan dengan kategori self esteem yang dimiliki oleh responden pada tabel dua diketahui bahwa tidak ada responden yang berada pada tingkatan kategori tinggi. Persebaran kategori responden terbagi dalam tingkatan kategori sedang dan rendah. Hal ini sesuai dengan pernyataan McKenna dkk (Rubin \& Coplan, 2010) yang menyebutkan bahwa orang-orang yang memiliki rasa malu, kecemasan sosial, atau kurangnya keterampilan sosial dapat merasa bebas untuk bertemu orang lain tanpa takut penolakan instan pada online dating. Rasa malu, kecemasan sosial dan kurangnya keterampilan sosial ini merupakan indikasi memiliki self esteem yang rendah. Yosep (Meryana, 2017) menyebutkan bahwa self esteem rendah berkaitan dengan adanya perasaan hilang kepercayaan diri, merasa gagal karena tidak mampu mencapai keinginan sesuai ideal diri, perasaan tidak berharga, tidak berarti dan rendah diri yang berkepanjangan akibat evaluasi yang negatif terhadap diri sendiri atau kemampuan diri (kompentensi).

Devito (2011) menjelaskan bahwa individu yang kompeten lebih banyak melakukan dalam pengungkapan diri daripada individu yang kurang kompeten. Hal ini berkaitan karena individu tersebut mempunyai rasa percaya diri yang diperlukan untuk lebih memanfaatkan self disclosure serta memliki banyak hal positif tentang dirinya sendiri untuk di ungkapkan daripada individu yang tidak kompeten.

Pada konteks yang berbeda berkaitan dengan kepribadian responden, perasaan gelisah atau kekhawatiran merupakan indikasi responden memiliki self esteem yang rendah. Devito (2011) menyebutkan bahwa perasan gelisah juga mempengaruhi derajat self disclosure, rasa gelisah adakalanya meningkatkan self disclosure individu dan kali lain menguranginya sampai batas minimum. Orang kurang berani bicara pada umumnya juga kurang self disclosure daripada mereka yang merasa lebih nyaman dalam berkomunikasi.

Keseluruhan hasil penelitian ini sesuai dengan penelitian terdahulu yang dilakukan oleh Sari, Andayani dan Masykur (2006), Mulatsih (2015), Prawesti dan Dewi (2016), Santi dan Damariswara (2017), Lestari dan Wijaya (2017), serta Adnan dan Hidayati (2018) bahwa self esteem dapat mempengaruhi self disclosure individu. Namun hasil penelitian ini berbeda dengan penelitian Seamon (2003) dan España (2012) yang menemukan bahwa tidak terdapat hubungan ataupun pengaruh antara self esteem terhadap self disclosure.

Adanya perbedaan hasil penelitian ini dimungkinkan karena pengaruh dari perbedaan budaya dan tempat penelitian. Penelitian ini memiliki hasil yang sama dengan penelitian terdahulu dikarenakan diteliti di Indonesia, dimana Indonesia memiliki budaya kolektif berbeda dengan negara barat yang memiliki budaya individual. Menurut Suler (Setyaningsih, 2014) kebudayaan diduga berpengaruh terhadap perilaku spesifik dalam penggunaan internet, apa yang diungkapkan di media sosial merupakan representasi dari harapan dan kebutuhan sesuai dengan latar belakang sosial dan budayanya. Hal ini diperjelas dalam penelitian Ardi dan Maison (Setyaningsih, 2014) yang membandingkan keterbukaan diri pada orang Indonesia sebagai representasi kebudayaan kolektif dan Polandia sebagai representasi kebudayaan individual.

Pada konteks budaya dalam self disclosure,sebagai data tambahan dalam penelitian peneliti juga melakukan perbandingan self disclosure pada konteks budaya yakni daerah domisili. Daerah yang diambil sebagai perbandingan yaitu dua daerah yang menjadi responden terbanyak dalam penelitian ini yakni Kalimantan Timur dan Jawa timur. Pada hasil perbandingan dalam konteks daerah, dengan menggunakan uji beda Mann Whitney ditemukan nilai sig. (2 tailed) sebesar $0,413(\mathrm{P}>0,05)$. Hal ini dimaknai bahwa tidak ada perbedaan tingkatan self disclosure pada daerah Kalimantan Timur dan Jawa Timur.

Pada konteks lainnya trust mepengaruhi self disclosure sebesar 22,5\% dan memiliki hubungan yang sedang. Pengaruh kekuatan sedang trust terhadap self disclosure dikarenakan adanya perasaan menyukai pada pengguna 
aplikasi kencan online. Dimana ketika sedang melakukan proses swipping, individu dapat melakukan filter pemilihan pada rekomendasi pasangan yang telah disediakan oleh sistem, ketika individu menyukai pilihan tersebut maka individu akan melakukan swipe ke kanan dan dapat berkomunikasi dengan calon pasangan yang telah di pilihnya. McKenna dkk (Rosen dkk, 2007) lebih detail menjelaskan hal tersebut yakni self disclosure mengarah pada peningkatan keintiman dan bahwa hanya setelah menyukai dan kepercayaan dibangun hubungan online dapat dibentuk.

Keseluruhan hasil penelitian ini sesuai dengan penelitian terdahulu yang dilakukan oleh Nisa (2012) dan Ganti, Mardianto \& Aviani (2016) bahwa terdapat pengaruh antara trust terhadap self disclosure pada individu. Hasil penelitian ini juga sesuai dengan pernyataan Bargh dkk (Rosen dkk, 2007) yakni hanya setelah membangun kepercayaan individu kemudian mulai mengungkapkan lebih banyak tentang diri mereka termasuk perasaan batin terdalam mereka.

Sebagai data tambahan, peneliti melakukan uji beda dengan menggunakan uji Mann whitney terhadap tingkatan self disclosure pada konteks jenis kelamin dan jenis aplikasi yang digunakan. Pada konteks jenis kelamin, berdasarkan hasil uji beda ditemukan hasil perbandingan dengan nilai sig. (2 tailed) sebesar 0,247 $(\mathrm{P}>0,05)$. Hal ini dimaknai bahwa tidak ada perbedaan tingkatan self disclosure antara laki-laki dan perempuan pengguna aplikasi kencan online. Temuan ini memiliki perbedaan dengan temuan penelitian terdahulu yang dilakukan oleh Sari, Andayani dan Masykur (2006), Yuliningsih (2015), serta Wahyuni dan Radjito (2017) yang menemukan bahwa terdapat berbedaan tingkatan self disclosure berdasarkan jenis kelamin. Dimana perempuan memiliki tingkatan self disclosure yang lebih tinggi dibandingkan laki-laki.

Disisi lain peneliti mencermati dari 325 responden $73,8 \%$ responden memilih untuk menggunakan aplikasi tan-tan atau tinder. Kedua aplikasi ini merupakan dua aplikasi terbanyak yang digunakan oleh subyek penelitian. Berdasarkan primary research berupa obsevasi partisipan yang dilakukan peneliti, ditemukan bahwa aplikasi tan-tan dan tinder memiliki kelebihan dalam kemudahan penggunaan aplikasi, lebih familiar serta kelebihan fitur yang diberikan dibandingkan dengan aplikasi kencan online lainnya. Pada aplikasi tan-tan contohnya dalam personal chatt hanya tidak hanya tersedia fitur chatting dengan teks atau gambar gif, tetapi juga terdapat fitur membagikan foto, video, lokasi dan suara dalam personal chatt. Selain itu aplikasi tan-tan juga memberikan fitur lebih dengan tambahan pilihan minat atau kesukaan yang dimiliki individu pada profilnya sehingga calon pasangan dapat melihat dan memilih tema sebelum melakukan komunikasi..

\section{KESIMPULAN}

Berdasarkan penelitian yang dilakukan, maka terdapat beberapa kesimpulan yang dapat diambil antara lain: pertama,Terdapat pengaruh self esteem dan trust terhadap self disclosure pada pengguna aplikasi kencan online. Kedua, Self esteem dan self disclosure memiliki hubungan yang lemah. Hal ini dikarenakan karakteristik kompetensi dan kepribadian responden mengindikasikan memiliki self esteem yang lemah sehingga mempengaruhi self disclosure yang dimilikinya. Ketiga, Trust dan self disclosure memiliki hubungan yang sedang. Hal ini dipengaruhi oleh faktor perasaan menyukai dari pasangan kencan online melalui kegiaatan sweeping rekomendasi pasangan sehingga mempengaruhi self disclosurenya.Keempat, Tidak ada perbedaan tingkatan self disclosure berdasarkan jenis kelamin, atau daerah domisili, pada responden pengguna aplikasi kencan online.

\section{DAFTAR PUSTAKA}

Adnan, A. Z., \& Hidayati, F. (2018). Self disclosue ditinjau dari tipe kepribadian dan self esteem pada remaja pengguna media sosial. Jurnal Psikologi Sains dan Profesi, 2 (2), 179-184.

Ben-Ze'ev, A. (2004). Love Online: emotions on the Internet. United Kingdom: Cambridge University Press.

Devito, J. A. (2011). Komunikasi antar manusia edisi kelima. Tanggerang: Karisma. 
Dewi, E. 2009. "Hubungan antara harga diri dengan kecendrungan metroseksual pada pria dewasa awal". Skripsi. Fakultas Psikologi, Universitas Sanata Dharma, Yogyakarta.

Gainau, M. B. (2009). Keterbukaan diri (self disclosure) siswa dalam perspektif budaya dan implikasinya bagi konseling. Jurnal Ilmiah Universitas Katolik Widia Mandala Madiun, 33 (1), 1-18.

Ganti, L. S., Mardianto, \& Aviani, I. Y. (2016). Hubungan trust pada media sosial facebook dengan self disclosure pada remaja. Periode Wisuda Juni 2016.

Hurlock, E. B. (2003). Psikologi perkembangan : suatu pendekatan sepanjang rentang kehidupan edisi kelima. Jakarta: Erlangga.

Kasali, R. (2018). The great shifting. Jakarta: Gramedia Pustaka Utama.

Lestari, D., \& Wijaya, Y. D. (2017). Hubungan harga diri dengan pengungkapan diri pada pria homoseksual di Jakarta. Jurnal Online, 1-6. Retrieved from https://digilib.esaunggul.ac.id/public/UE U-Undergraduate-7796-JURNAL.pdf

Lumongga, N. (2016). Depresi: Tinjauan Psikologis. Jakarta: Kencana.

Mulatsih, T. (2015). "Hubungan self esteem dengan self disclosure pada remaja saat chatting di internet". Skripsi. Fakultas Psikologi, Universitas Islam Negeri Sultan Syarif Kasim Riau, Pekanbaru.

Meryana. (2017). Upaya meningkatkan harga diri dengan kegaiatan positif pada pasien harga diri rendah. Publikasi Ilmiah.

Mikyoung, K., Kwon, K.-N., \& Mira, L. (2009). Psychological characteristics of internet dating service users: the effect of selfesteem, involvement, and sociability on the use of internet dating services.
CYBERPSYCHOLOGY \&

BEHAVIOR, 12(4), 445-449.

Morrison, P., \& Burnard, P. (2009). Caring and communicating hubungan interpersonal dalam keperawatan. Jakarta: Buku Kedokteran EGC.

Nisa, I. (2012). "Hubungan antara trust dengan self-disclosure pada hubungan pertemanan". Skripsi. Fakultas Psikologi, Universitas Muhammadiyah Malang, Malang.

Nöstlinger, C., Kitaka, S. B., Buyze, J., Loos, J., \& Buvé, A. (2015). Factors influencing social self-disclosure among adolescents living with HIV in Eastern Africa. AIDS Care, 1(1),36-46.

Nugroho, Z. S. (2017). "Program hipotetik bimbingan dan konseling pribadi dan sosial untuk mengurangi kencedrungan shyness (studi deskriptif terhadap Siswa SMP N 4 Bandung tahun ajaran 2016/2017)". Skripsi. Fakultas Ilmu Pendidikan, Universitas Pendidikan Indonesia, Bandung.

Pinakesti, A. R. 2016. "Self disclosure dan stress pada mahasiswa". Skripisi. Fakultas Psikologi, Universitas Muhammadiyah Malang, Malang.

Putri, M. D., \& Kusumaputri, E. S. (2014). Kepercayaan (trust terhadap pengurus organisasi dan komitmen afektif pada organisasi mahasiswa daerah di Yogyakarta. Jurnal Psikologi Integratif, 2(1), 53-61.

Prawesti, F. S., \& Dewi, D. K. (2016). Self esteem dan self disclosure pada mahasiswa psikologi pengguna blackberry messenger. Jurnal Psikologi Teori dan Terapan, 7(1), 1-8.

Riyanto, T., \& Susanto, H. (2009). Mau Bahagia. Yogyakarta: Kanisius. 
Rosen, L. D. (2007). Me, my space, and i: parenting the net generation. New York: St. Martin's Press.

Rubin, K. H., \& Coplan, R. J. (2010). The development of dhyness and social withdrawal. New York: Guilford Press.

Santi, N. N., \& Damariswara, R. (2017). Hubungan antara self esteem dengan self disclosure pada saat chatting di facebook. Pedagogia : Jurnal Pendidikan, 6(1), 110123.

Santrock, J. W. (2012). Perkembangan masa hidup. Jakarta: Erlangga.

Sari, R. P., Andayani, T. R., \& Masykur, A. M. (2006). Pengungkapan diri mahasiswa tahun pertama universitas diponegoro ditinjau dari jenis kelamin dan harga diri. Jurnal Psikologi Universitas Diponegoro, 3(2), 11-25.

Seamon, C. M. (2003). Self-esteem, sex differences, and self-disclosure: a study of the closeness of relationships. The Osprey Journal of Ideas and Inquiry, 153-167.

Setyaningsih, R. (2014). Memahami hubungan kebutuhan untuk populer dan keterbukaan diri (self-disclosure) pada pengguna facebook: sebuah tinjauan literatur. Proyeksi, 11(1), 93-104.

Suaib, H. (2017). Suku Moi: nilai-nilai kearifan lokal dan modal sosial dalam pemberdayaan masyarakat. An1mage.net.

Taneira, G. P. 2019. "Hubungan antara kepercayaan terhadap pasangan dan kepuasan perkawinan pada istri tentara batalyon X”. Skripsi.Fakultas Psikologi, Universitas Sanata Dharma, Yogyakarta.

Upton, P. (2012). Psikologi perkembangan. Jakarta: Erlangga.
Wahyuni, L. D., \& Radjito. (2017). Dukungan sosial dan pengungkapan diri pada peserta didik program kesetaraan paket B. Jurnal Penelitian dan Pengukuran Psikologi, 6(1), 7-16.

Ward, J. (2016). Swiping, matching, chatting: self-presentation and self-disclosure on mobile dating apps. Human IT, 13(2), 82-95.

Yulianti, A. (2015). Emosional distress dan kepercayaan terhadap pasangan yang menjalani commuter marriage. Seminar Psikologi \& Kemanusiaan, 21-25. 